\title{
ANALYSIS OF THE EFFECT OF THE PHASED INTRODUCTION OF ADDITIVES ON MAINTAINING THE MOBILITY OF CONCRETE MIX FOR MONOLITHIC HOUSING CONSTRUCTION
}

\author{
${ }^{1}$ Savchenko S.V., PhD., Assistant Professor, \\ koval_sv@ukr.net, ORCID:0000-0002-4973-0552 \\ 1 Koval S.V., Doctor of Engineering, Professor, \\ ${ }^{1}$ Odessa State Academy of Civil Engineering and Architecture \\ 4, Didrichson street, Odessa, 65029, Ukraine
}

\begin{abstract}
Trends in the development of modern monolithic housing construction show the need to increase the viability of the concrete mixture and determine the feasibility of using the method of «late» introduction of additives («two-step mixing method»), which consists in the introduction of additives in two stages. At the first stage, to increase the viability of the mixture and lengthen the injection period of hardening, which is especially important for laying concrete at elevated temperatures, plasticizer and hardening inhibitor additives are introduced into the concrete mixture. At the second stage, immediately before laying and compacting the concrete mixture in the structure, the secondary dosage of additives and the hardening accelerator are introduced into the concrete mixture. This method allows restoring the mobility of the concrete mixture by adding a very small amount of water included in the working solution of the additive.

The effect of repeated introduction of additives on the kinetics of plastic strength is analyzed. The analysis showed, firstly, the possibility of a sharp decrease in structural strength at the time of introduction of additional additives; secondly, the possibility of lengthening the induction period, which prolongs the shelf life of the mixture; thirdly, the additional introduction of the accelerator as part of the "secondary" complex additive allowing accelerating the set of plastic strength of cement paste, which should positively affect the growth of early concrete strength in the structure.

To test the effect of this additives introducing scheme on early strength and in the later stages of hardening, special experiments were performed on a 15-point D-optimal plan, in which the concentrations of superplasticizer, moderator and accelerator were varied. Based on the obtained models of physical and mechanical properties, the influence of various concentrations of additives on the early strength of concrete in the structure and in a later period is analyzed. The areas of optimal concentrations of additives were determined.

The proposed method of working with concrete mixture under conditions of prolonged transportation and at increased temperatures allows the use of additives of different types and their combination separately at different stages, depending on the time of year, the organization of concrete work, the distance to the construction site, taking into account the cost of transportation and other factors.
\end{abstract}

Keywords: concrete, mobility, phased method, superplasticizer, moderator, accelerator, strength.

Introduction. In recent decades, concrete production technology has identified a tendency to use easily blendable mixtures including self-compacting concretes [1, 2]. However, as seen from practical experience, there exists a risk of mobility loss of concrete mixtures, especially at times of long transportation and in higher temperatures. Hydrating after transportation causes a decrease in strength and a deterioration in the performance characteristics of concrete.

Analysis of recent research and publications. The need to increase the strength of the concrete mixture determines the expedience of using the two-stage mixing method [3]. The mobility retention time can be extended by dispensing the superplasticizer in portions (Fig. 1). The number of portions should not be large, as repeated dosing can cause the formation of frail structure and the decrease in strength of concrete [4].

Bulletin of Odessa State Academy of Civil Engineering and Architecture, 2020, no. 78, page 118-125 

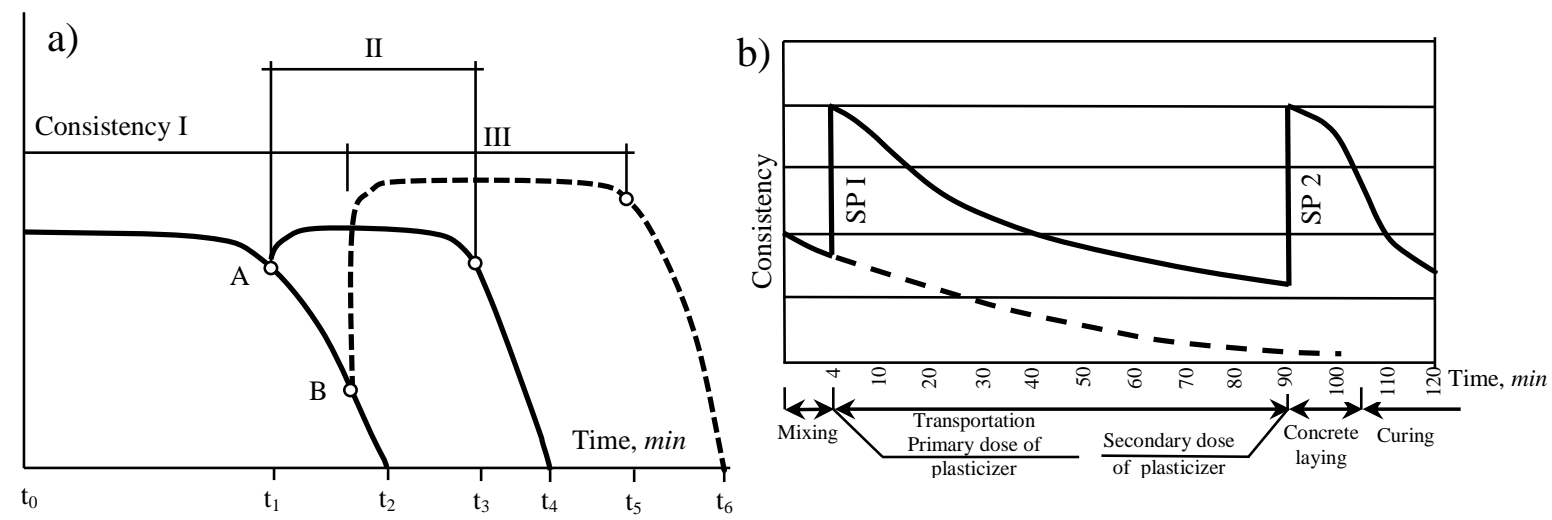

Fig. 1. Pattern (a) of gradual dosing of the superplasticizer $\left(t_{1}, t_{2}, t_{3}-\right.$ initial time of decrease in effect; I, II and III - periods of full effect; A and B - the time of introduction of the next portion) [1], as well as the effect of such dosage [2] (b)

Recurring dosing can be divided into primary portion (the introduction of plasticizer during the preparation of the mixture) and secondary portion - just before the laying and curing of the concrete mixture in the structure [1-4].

We have made the assumption that this method can be improved from the standpoint of solving the above mentioned engineering problem by using different types of additives that are introduced gradually.

Ensuring the specified parameters of technological mixtures in the conditions of their long transportation without slowing the curing process is a difficult engineering task in monolithic construction [1]. This task can be solved by the stagewise introduction of additives. Plasticizing surfactants, including superplasticizers (SPs), are used to control the technological properties of the mixture. At the same time, the mixtures modified by these additives are characterized by a fairly rapid loss of ease of laying. To prevent this phenomenon, the superplasticizer can be added in portions - one part when preparing concrete mixes at concrete mixing unit, and another at the place of laying the concrete mixture into the structure (usually, the solution of the additive is poured directly under the rotating drum of the concrete mixer).

This method allows to restore the mobility of the concrete mixture without adding very little water included in the working solution of the additive. However, the prepared mobile concrete mixture cannot quickly gain strength after laying it in the structure due to the slowing effect of the additional portion of the superplasticizer. As already mentioned, slowing down the curing process does not make it possible to increase the turnover of the formwork and to perform the transfer of load.

The following hypothesis is stated. Since the introduction of SP leads to a decrease in early strength [5], to compensate for its loss before laying the mixture in the formwork, it is advisable, at the time of reintroduction of the superplasticizer, to additionally introduce a curing accelerator, which can be particularly effective in coordination with the processes of structure formation.

The purpose of this research is to increase the preservation of the concrete mixture and to regulate the kinetics of curing of concrete in course of the gradual introduction of additives.

Objects and methods of research. Portland cement of type CEM 145.2 of brand PC 1-500 produced at the Olshansk plant was used for the preparation of mortars and concrete. The additives used were the standard C-3 superplasticizer, the Isola VZ-520 retarder, and the $\mathrm{Na}_{2} \mathrm{SO}_{4}$ curing accelerator.

The sand of Bilyaev deposit with the size modulus of $\mathrm{M}_{\mathrm{K}}=1.6$ was used as a small filler. Crushed granite stone of fraction 5-10 was gradually introduced into that of fraction 5-20. The highest value of bulk density of the crushed granite mixture was noted when introducing $40 \%$ of fraction 5-10 into that of large fraction 5-20.

The measurement of plastic strength was carried out on a Rebinder plastometer, the design of which allows to measure the amount of immersion of the cone in the researched mixture with a mechanical lift of the table which automatically stops when reaching the specified load by opening 
the contacts of the microswitch. The recording device ConReg 712 produced by GSM-instrument company was used to measure the temperature of the curing solution.

The quality of the concrete mixture was evaluated according to the methods of the European Commission on self-compacting concrete. The diameter and time of flow of the cone of the concrete mixture were determined. The strength characteristics of the researched solutions were studied on the samples of beams of $40 \times 40 \times 160 \mathrm{~mm}$, which were cured at normal and at higher temperatures.

The search for solutions of engineering problems was performed using the multifactorial experimental and statistical models calculated on the basis of the results of experiments carried out under optimal plans.

Research results. We have analyzed the change in time of plastic strength of cement pastes with the usual and repeated introduction of additives.

Fig. 2 shows the change in the time of plastic strength of cement pastes with the usual (curve 1) and repeated (curve 2) introduction of superplasticizer, as well as with the additional introduction of the complex additive «superplasticizer + curing accelerator» (curve 3 ).

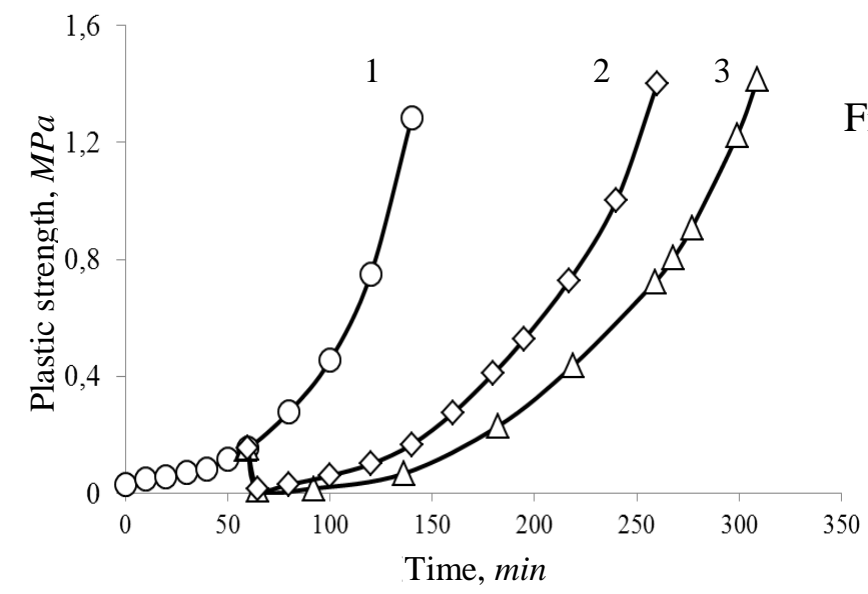

Fig. 2. Kinetics of plastic strength with the stagewise introduction of additives: 1 - superplasticier according to the usual pattern; $2-60 \%$ of the SP when preparing the mixture and $40 \%$ of the SP before laying $+1,2 \%$ of the accelerator; 3 - two-stage introduction of the SP $(60 \%+40 \%)$

Naturally, the increase in strength is also influenced by the process of repeated mixing itself, but the clearly visible difference in kinetics allows us to state the predominant effect of namely additives rather than that of the mixing process with the introduction of additional portions of additives.

The analysis of the kinetics of plastic strength (Fig. 2) indicates, firstly, the risk of a sheer decrease in structural strength at the time of introduction of additional additives; secondly, the possibility of extending the induction period, which extends the time of preserving the mobility of the mixture; and thirdly, the additional introduction of the accelerator in the composition of the «secondary» complex additive allows to accelerate the gaining of plastic strength by the cement paste, which should have a positive impact on the growth of early strength of concrete in construction.

The temperature dependencies (Fig. 3) indicated a change in the rate of hydration of cement [6] when applying stagewise introduction of additives.

The superplasticizer introduced in conjunction with water is intensively absorbed by the surface of $\mathrm{C}_{3} \mathrm{~A}, \mathrm{C}_{3} \mathrm{~S}$, as well as ettringite formed in the first stage as a result of the reaction of $\mathrm{C}_{3} \mathrm{~A}$ and gypsum [7]. As a result of the formation of new surfaces, the content of the additive decreases rapidly in the liquid phase, and the exposure of the active centers of the particles that continue to interact with water leads to the acceleration of the reaction. This is reflected in the increase in the hydration temperature (curve 1, Fig. 3).

In the case of repeated introduction of superplasticizer, a new amount of additive will appear in the liquid phase. This will renew its absorption and again cover the active centers of the cement particles with the surfactant molecules. As a result, the heat dissipation decreases, which indicates the slowing of the hydration process (curve 3, Fig. 3). 


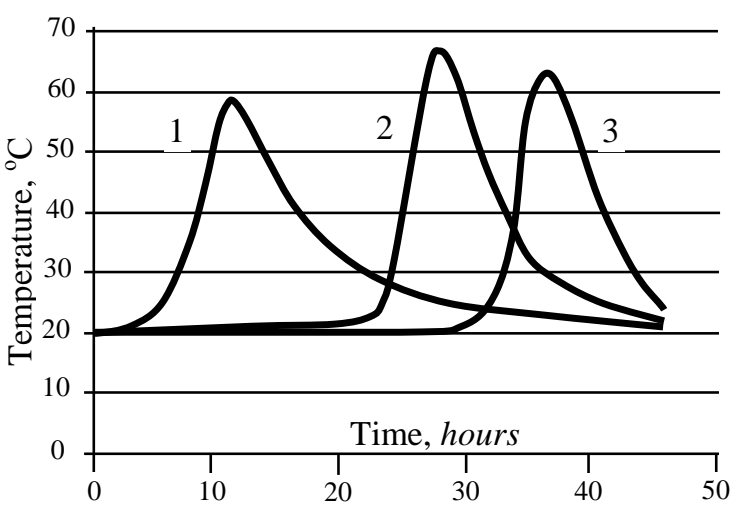

Fig. 3. Change of temperature of hydration during stagewise introduction of additives: 1 - SP in the usual pattern; $2-60 \%$ SP during preparation of the mixture and $40 \%$ SP before laying + $1,2 \%$ accelerator; 3 - two-stage introduction of SP $(60 \%+40 \%)$

If we evaluate the effect of the repeated introduction according to the pattern of «initial deceleration with subsequent acceleration», the greatest effect would be shown in the addition of $40 \%$ of the SP with the accelerator in $60 \mathrm{~min}$. (curve 2, Fig. 3), since with the increase of the induction period, the temperature maximum is reached earlier compared to the introduction of the superplasticizer in a repeated dose.

Apart from the introduction of the accelerator, the possibility of solving the set task in the case of introduction of the retarder for a significant extension of the period of preservation of mobility of the concrete mixture, which is particularly relevant when conducting construction works in higher temperatures.

The pattern of influence of additives (superplasticizer, retarder, accelerator) with stagewise introduction is shown in Fig. 4.

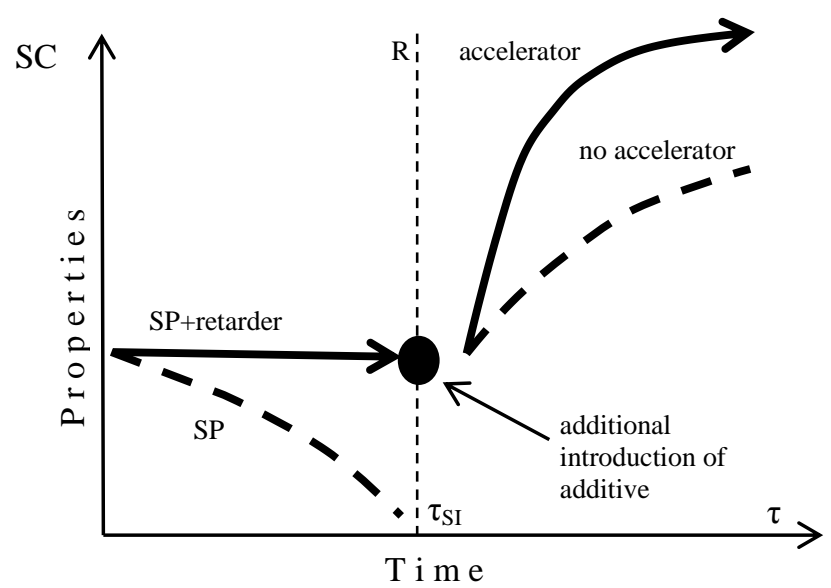

Fig. 4. Pattern of the effect of three additives in a stagewise introduction

To test this pattern, special experiments were performed on a 15-point D-optimal plan, which varied the concentrations of the superplasticizer, retarder and accelerator. The pattern of formation of factor space is shown in Fig. 5. In accordance with the general recommendations $[8,9]$, the level $x_{i}=-1$ is combined with zero concentration of additives (point No.1), which allows to research the composition without additives on models SC and $\mathrm{R}$, as well as the compositions with individual and double additives.

The points No.2-No.5 correspond to the composition of the «primary» equilibrium mixture (cone sediment $\mathrm{SC}_{0}=18 \pm 0,2 \mathrm{~cm}$ ) with variable concentrations of standard

superplasticizer C-3 (factor $\mathrm{X}_{2}$ ) and retarder Isola VZ-520 (factor $\mathrm{X}_{3}$ ).

The experiments at five base points are supplemented at the first stage by designing the mixtures at points No.6-No.10, but in this case the mixtures did not contain any accelerator $\left(\mathrm{X}_{1}=0 \%\right.$, the factor indexed as $\mathrm{x}_{1}=-1$ ). The mixtures obtained in these research points had the curing accelerator $\mathrm{Na}_{2} \mathrm{SO}_{4}$ introduced into them at variable doses after 2 hours-long infusion at the temperature of $28 \pm 1{ }^{\circ} \mathrm{C}$. The conservation index for the mobility of the mixture was calculated as (1):

$$
\mathrm{C}=\left(\mathrm{SC}_{0}-\mathrm{SC}_{\tau=2}\right) / \mathrm{SC}_{0}, \%
$$

where $\mathrm{SC}_{0}$ - the output mobility $18 \mathrm{~cm}$;

$\mathrm{SC}_{\tau=2}-$ mobility after 2 hours-long infusion. 


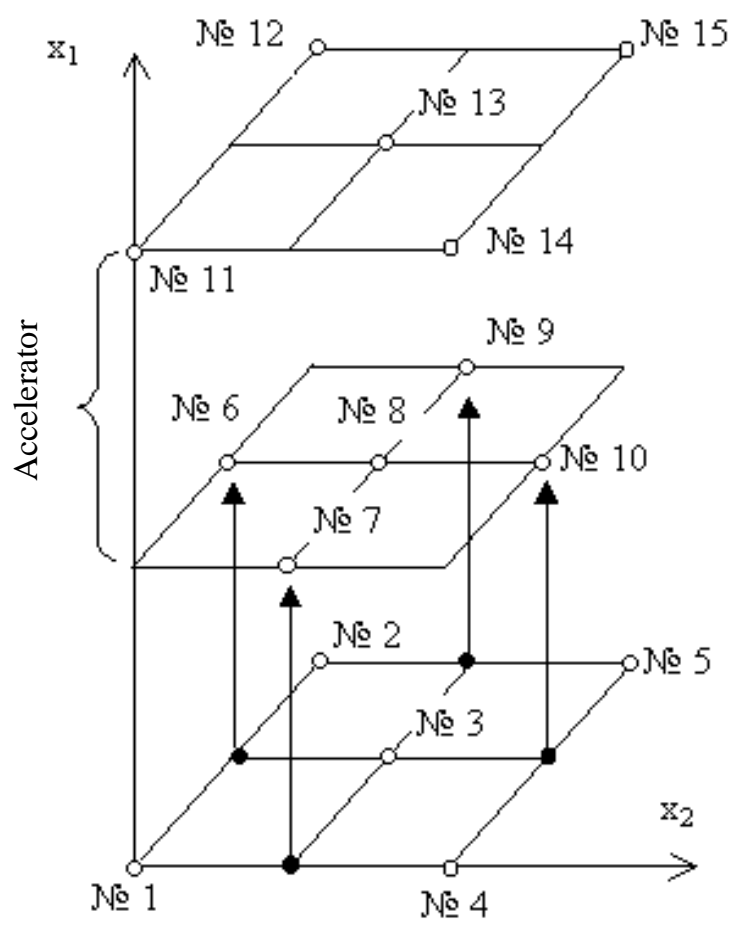

Fig. 5. Location of the trial points in the factor space
Table 1 - Levels of variation in dosing the additives

\begin{tabular}{|c|c|c|c|c|c|c|}
\hline \multirow[t]{2}{*}{ No } & \multicolumn{3}{|c|}{ The code } & \multicolumn{3}{|c|}{ Dosage, $\%$} \\
\hline & $\mathrm{x}_{1}$ & $\mathrm{x}_{2}$ & $\mathrm{x}_{3}$ & Accel. & SP & Retar. \\
\hline 1 & \multirow{5}{*}{-1} & -1 & -1 & \multirow{5}{*}{0} & 0 & 0 \\
\hline 2 & & -1 & +1 & & 0 & 0,02 \\
\hline 3 & & 0 & 0 & & 0,3 & 0,01 \\
\hline 4 & & +1 & -1 & & 0,6 & 0 \\
\hline 5 & & +1 & +1 & & 0,6 & 0,02 \\
\hline \multicolumn{7}{|c|}{ Additional introduction of accelerator } \\
\hline 6 & \multirow{5}{*}{0} & -1 & 0 & \multirow{5}{*}{1,5} & 0 & 0,01 \\
\hline 7 & & 0 & -1 & & 0,3 & 0 \\
\hline 8 & & 0 & 0 & & 0,3 & 0,01 \\
\hline 9 & & 0 & +1 & & 0,3 & 0,02 \\
\hline 10 & & +1 & 0 & & 0,6 & 0,01 \\
\hline 11 & \multirow{5}{*}{+1} & -1 & -1 & \multirow{5}{*}{3,0} & 0 & 0 \\
\hline 12 & & -1 & +1 & & 0 & 0,02 \\
\hline 13 & & 0 & 0 & & 0,3 & 0,01 \\
\hline 14 & & +1 & -1 & & 0,6 & 0 \\
\hline 15 & & +1 & +1 & & 0,6 & 0,02 \\
\hline
\end{tabular}

In the study of the method of two-stage introduction of additives, the ES-designing has a number of features, in particular, each model describes both the initial and the «belated» effects of their introduction.

The effect of three additives on the strength of concrete after the first day of curing under normal conditions in the zone of the maximum and minimum of $\mathrm{R}_{1}$ is shown in Fig. 6, a. The effect of the accelerator on the strength of the concrete after one day of curing can be compared with the superplasticizer, with full compensation for the negative effect of the retarder being a possibility, especially with the introduction of the SP and curing regulator in optimal dosages.

A graphical solution to the problem of additive selection is shown in Fig. 6, b. The lower face of the cube reflects the effect of the superplasticizer $\left(\mathrm{X}_{2}\right)$ and the retarder $\left(\mathrm{X}_{3}\right)$, which are introduced directly when preparing the mixture. Axis $\mathrm{X}_{1}$ shows the effect of the accelerator introduced after a 2 hours-long infusion, and the combined effect of the three additives is observed inside the cube.

A selected region of concentrations of modifiers is formed in the space $\left\{X_{1}, X_{2}, X_{3}\right\}$, in which, given the stagewise method of their introduction, the mobility of the concrete mixture is reduced by less than $\mathrm{C}=50 \%$ after 2 hours-long $\left(\mathrm{t}=+28{ }^{\circ} \mathrm{C}\right)$ infusion while providing the strength of $\mathrm{R}_{1} \geq 15 \mathrm{MPa}$, normalized for monolithic concrete.

The analysis of iso-surfaces in Fig. 6 shows that at higher concentrations of the superplasticizer and the accelerator, the strength of the modified composite is increased by $60 \%$ or more compared to the additive-free composite. However, in the region of high values of $\mathrm{X}_{2}$ and $\mathrm{X}_{3}$ the retardery effect (within this experiment) of Vizola concentration is reduced. It can be concluded from the graphical analysis of the model that the accelerator and the superplasticizer are characterized by positive impact on $\mathrm{R}$ as a result of change in the kinetics of the reactions (the strength is increased by more than 1,8 times compared to the standard). Further analysis showed that mortars with such concentrations of additives have the highest strength after 60 days, which is probably due to the favorable effect of additives on the formation of the cement stone structure. 

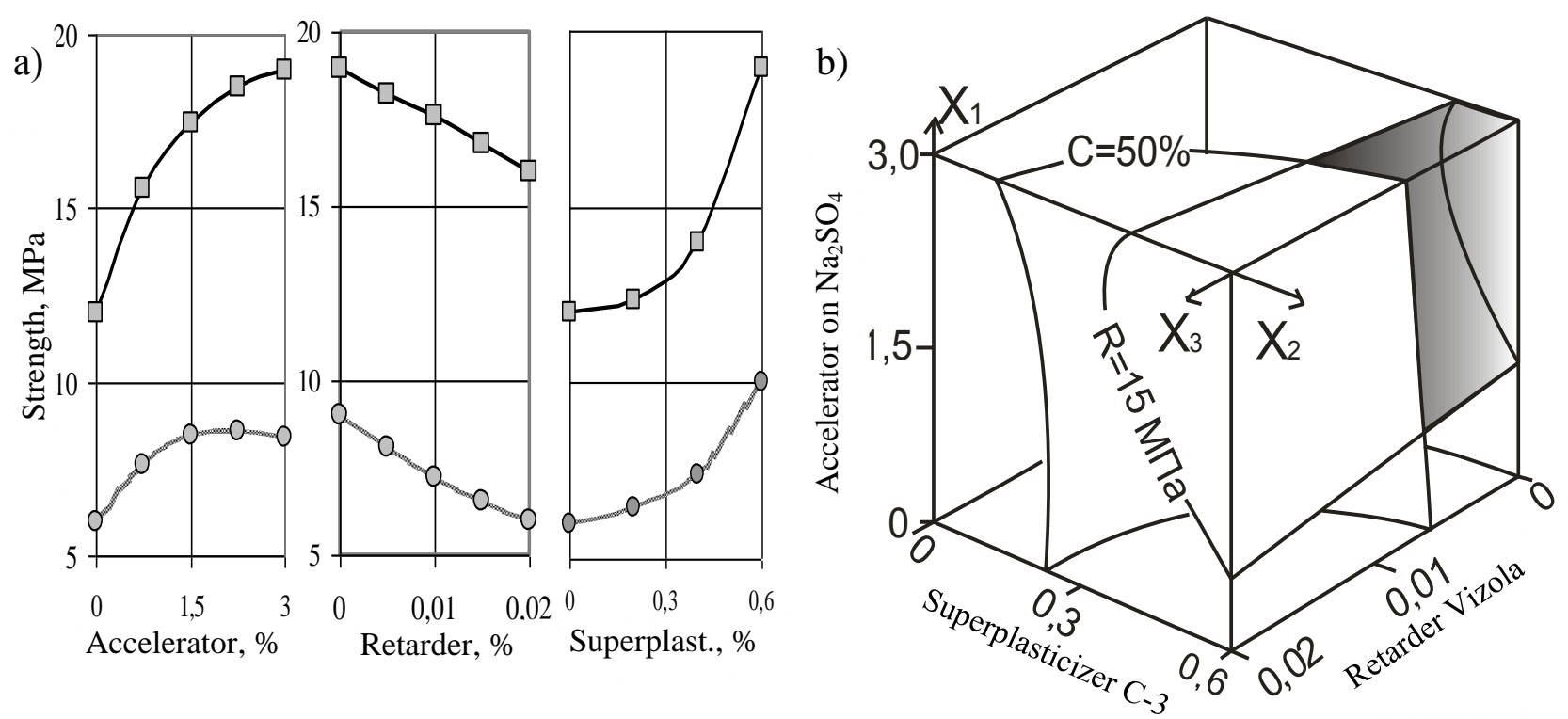

Fig. 6. Influence of ingredients in the zones of maximum and minimum $\mathrm{R}_{1}$ (a) search for a compromise area for additive concentrations (b)

Not only imported retarders, but also more affordable additives, including technical lignosulfonates and feed molasses can be used as ingredients of multifunctional additives. Depending on the requirements for concrete, any additive may be excluded from or added to the pattern. Thus, it is possible to apply a two-stage pattern of introducing modifiers, and their efficiency can be increased when the effect of additives is consistent with the processes of structure formation [7].

Conclusion and prospects for further research. We have suggested a method of operating with concrete mixtures at times of long transportation and at higher temperatures, namely the twostage introduction of additives. Additives of different types (plasticizers, superplasticizers, retarders, accelerators) are combined and introduced separately at different stages depending on the time of year, the scheme of organization of concrete works, the distance to the construction site, taking into account the cost of transportation and other factors. This also allows avoiding the introduction of excess water into the mixer (the amount of water is taken into account when designing the concrete composition) to restore the mobility of the concrete mixture lost during transportation, and thus avoiding the lowering of the concrete strength class in the structure.

\section{References}

[1] A.M. Neville, Właściwości betonu. Wydanie czwarte, Wydawnictwo Polski Cement. Kraków, 2000.

[2] Z. Jamroży, Beton i jego technologie. Nowe wydanie uwzględniające PN-EN206-1. Warszawa: Wyd. PWN, 2005.

[3] G. Chiocchio, A. Paolini, "Optimum time for adding superplasticizer Portland", Cem. Conc, Pe. 15 (5), pp. 901- 908, 1985.

[4] I. Aiad, S. Abd El-Aleem, H. El-Didamony, "Effect of delaying addition of some concrete admixtures on the rheological properties of cement pastes", Cement and Concrete Research, Pe. 32, pp. 1839-1843, 2002.

[5] V.S. Ramachandral, R.F. Feldman, M. Kollepardi etc., Concrete additives: Reference book. Moskva: Stroyizdat, 1988.

[6] M. Tsyak, "Thermokinetic features of cement hydration during the phased introduction of additives into the concrete mix", Visnyk DonDABA (Composite building materials), 
Makiyivka: DonDABA, Vol. 5(61), pp. 110-115, 2009.

[7] H. Teylor, Cemenet chemistry. Moskva: Mir, 1986.

[8] S. Koval, Modeling and optimization of the composition and properties of modified concrete: monograph. Odessa: Astroprint, 2012.

[9] S. Koval, Effective concrete for monolithic housing construction: monograph. Odessa: Astroprint, 2015.

\title{
АНАЛІЗ ВПЛИВУ ПОЕТАПНОГО ВВЕДЕННЯ ДОБАВОК НА ЗБЕРЕЖЕННЯ РУХЛИВОСТІ БЕТОННОЇ СУМІШ ДЛЯ МОНОЛІТНОГО ДОМОБУДУВАННЯ
}

\author{
${ }^{1}$ Савченко С.В., к.Т.н., доцент, \\ koval_sv@ukr.net, ORCID: 0000-0002-4973-0552 \\ Коваль С.В., д.т.н., професор, \\ ${ }^{1}$ Одеська державна академія будівництва та архітектури \\ вул. Дідріхсона, 4, м. Одеса, 65029, Україна
}

\begin{abstract}
Анотація. Тенденції в розвитку сучасного монолітного домобудівництва показують на необхідність підвищення життєздатності бетонної суміші i визначають доцільність використання методу «запізнілого» введення добавок («two-step mixing method»), що полягає у введенні добавок в два етапи. На першому етапі для підвищення життєздатності суміші i подовження індукційного періоду твердіння, що особливо актуально для укладання бетону при підвищених температурах, при приготуванні в бетонну суміш вводяться добавки пластифікатора і сповільнювача твердіння. На другому етапі безпосередньо перед укладанням i ущільненням бетонної суміші в конструкції в бетонну суміш вводиться вторинне дозування СП і прискорювача твердіння. Цей спосіб дозволяє відновити рухливість бетонної суміші при додаванні вельми малої кількості води, що входить в робочий розчин добавки.

Проаналізовано вплив повторного введення добавок на кінетику пластичної міцності. Аналіз показав, по-перше, можливість різкого зменшення структурної міцності в момент введення додаткових добавок; по-друге, можливість подовження індукційного періоду, що подовжує час збереження суміші; по-третє, додаткове введення прискорювача в складі «вторинної» комплексної добавки дозволяе прискорити набір пластичної міцності цементного пасти, що повинно позитивно позначитися на зростанні ранньої міцності бетону в конструкції.

Для перевірки впливу даної схеми введення добавок на ранню міцність і в більш пізні терміни твердіння були поставлені спеціальні експерименти по 15-ти точковому Dоптимального плану, в якому варіювалися концентрації суперпластифікатора, сповільнювача i прискорювача. За отриманими моделями фізико-механічних властивостей проаналізовано вплив різних концентрацій добавок на ранню міцність бетону в конструкції і в більш пізній період. Визначено області оптимальних концентрацій добавок.

Запропонований метод робіт з бетонною сумішшю в умовах тривалого транспортування і при підвищених температурах, дозволяє використовувати добавки різних типів і комбінувати їх введення окремо на різних етапах в залежності від пори року, схеми організації бетонних робіт, відстані до будівельного майданчика, з урахуванням вартості перевезень і інших факторів.
\end{abstract}

Ключові слова: бетон, рухливість, поетапний спосіб, суперпластифікатор, сповільнювач, прискорювач, міцність. 


\title{
АНАЛИЗ ВЛИЯНИЯ ПОЭТАПНОГО ВВЕДЕНИЯ ДОБАВОК НА СОХРАНЕНИЕ ПОДВИЖНОСТИ БЕТОННОЙ СМЕСИ ДЛЯ МОНОЛИТНОГО ДОМОСТРОЕНИЯ
}

\author{
${ }^{1}$ Савченко С.В., к.т.н., доцент, \\ koval_sv@ukr.net, ORCID: 0000-0002-4973-0552 \\ 1 Коваль С.В., д.т.н., профессор, \\ ${ }^{1}$ Одесская государственная академия строительства и архитектурь \\ ул. Дидрихсона, 4, г. Одесса, 65029, Украина
}

\begin{abstract}
Аннотация. Тенденции в развитии современного монолитного домостроения показывают на необходимость повышения жизнеспособности бетонной смеси и определяют целесообразность использования способа «запоздалого» введения добавок («two-step mixing method»), заключающегося во введении добавок в два этапа. На первом этапе для повышения жизнеспособности смеси и удлинения индукционного периода твердения, что особенно актуально для укладки бетона при повышенных температурах, при приготовлении в бетонную смесь вводятся добавки пластификатора и замедлителя твердения. На втором этапе непосредственно перед укладкой и уплотнением бетонной смеси в конструкции в бетонную смесь вводится вторичная дозировка СП и ускоритель твердения. Этот способ позволяет восстановить подвижность бетонной смеси при добавлении весьма малого количества воды, входящей в рабочий раствор добавки.

Проанализировано влияние повторного введения добавок на кинетику пластической прочности. Анализ показал, во-первых, возможность резкого уменьшения структурной прочности в момент введения дополнительных добавок; во-вторых, возможность удлинения индукционного периода, что продлевает время сохранности смеси; в третьих, добавочное введение ускорителя в составе «вторичной» комплексной добавки позволяет ускорить набор пластической прочности цементной пасты, что должно положительно сказаться на росте ранней прочности бетона в конструкции.

Для проверки влияния данной схемы введения добавок на раннюю прочность и в более поздние сроки твердения были поставлены специальные эксперименты по 15-ти точечному Dоптимальному плану, в котором варьировались концентрации суперпластификатора, замедлителя и ускорителя. По полученным моделям физико-механических свойств проанализировано влияние различных концентраций добавок на раннюю прочность бетона в конструкции и в более поздний период. Определены области оптимальных концентраций
\end{abstract} добавок.

Предложенный метод работ с бетонной смесью в условиях длительного транспортирования и при повышенных температурах, позволяет использовать добавки разных типов и комбинировать их введение по отдельности на разных этапах в зависимости от поры года, схемы организации бетонных работ, расстояния до строительной площадки, с учетом стоимости перевозок и других факторов.

Ключевые слова: бетон, подвижность, поэтапный способ, суперпластификатор, замедлитель, ускоритель, прочность.

Стаття надійшла до редакції 17.01.2020

Bulletin of Odessa State Academy of Civil Engineering and Architecture, 2020, no. 78, page 118-125 